\title{
The Number of Glutamate Transporter Subtype Molecules at Glutamatergic Synapses: Chemical and Stereological Quantification in Young Adult Rat Brain
}

\author{
Knut P. Lehre and Niels C. Danbolt \\ Department of Anatomy, Institute of Basic Medical Sciences, University of Oslo, N-0317 Oslo, Norway
}

The role of transporters in shaping the glutamate concentration in the extracellular space after synaptic release is controversial because of their slow cycling and because diffusion alone gives a rapid removal. The transporter densities have been measured electrophysiologically, but these data are from immature brains and do not give precise information on the concentrations of the individual transporter subtypes. Here we show by quantitative immunoblotting that the numbers of the astroglial glutamate transporters GLAST (EAAT1) and GLT (EAAT2) are 3200 and 12,000 per $\mu \mathrm{m}^{3}$ tissue in the stratum radiatum of adult rat hippocampus (CA1) and 18,000 and 2800 in the cerebellar molecular layer, respectively. The total astroglial cell surface is 1.4 and $3.8 \mathrm{~m}^{2} / \mathrm{cm}^{3}$ in the two regions, respectively, implying average densities of GLAST and GLT molecules in the membranes around 2300 and $8500 \mu \mathrm{m}^{-2}$ in the former and 4700

The glutamate uptake system (Danbolt et al., 1998) consists of at least five different transporter proteins (GLAST/EAAT1, GLT/ EAAT2, EAAC/EAAT3, EAAT4, and EAAT5) and represents the only mechanism for removal of excitatory amino acids from the extracellular fluid in the brain. Its importance for the longterm maintenance of low extracellular concentrations of glutamate is well documented (for review, see Danbolt, 1994; Robinson and Dowd, 1997).

The roles of these transporters during the first millisecond after synaptic release of glutamate, however, is currently being debated. Mathematical models (Holmes, 1995; Clements, 1996; Kleinle et al., 1996; Barbour and Häusser, 1997) suggest that passive diffusion alone causes a rapid decline in the glutamate concentration in the synaptic cleft after release. Considering the slow kinetics of the glutamate transporters [a cycling time of 50-100 msec (Wadiche et al., 1995)], it has been argued (Otis et al., 1996) that glutamate uptake is important only for the slow components of glutamate removal and for the ambient glutamate levels. However, the glutamate transporters could buffer glutamate on a submillisecond time scale by binding rather than by transport if they are present in sufficient numbers close to the release sites (Tong and Jahr, 1994). There is now experimental evidence for a rapid effect of the transporters (Barbour et al.,

\footnotetext{
Received June 26, 1998; revised Aug. 17, 1998; accepted Aug. 21, 1998.

We thank Jon Storm-Mathisen, Ole Petter Ottersen, and Theodor Blackstad for discussions. This work was supported by European Union BIOMED II (contract BMH4-CT95-0571), Schreiners fond, Bruuns fond, Nansenfondet, and the Norwegian Research Council.

Correspondence should be addressed to Dr. Niels C. Danbolt, Department of Anatomy, Institute of Basic Medical Sciences, University of Oslo, P.O. Box 1105 Blindern, N-0317 Oslo, Norway.

Copyright (C) 1998 Society for Neuroscience $\quad 0270-6474 / 98 / 188751-07 \$ 05.00 / 0$
}

and $740 \mu \mathrm{m}^{-2}$ in the latter region. The total concentration of glial glutamate transporters in both regions corresponds to three to five times the estimated number of glutamate molecules in one synaptic vesicle from each of all glutamatergic synapses. However, the role of glial glutamate transporters in limiting synaptic spillover is likely to vary between the two regions because of differences in the distribution of astroglia. Synapses are completely ensheathed and separated from each other by astroglia in the cerebellar molecular layer. In contrast, synapses in hippocampus (stratum radiatum) are only contacted by astroglia and are often found side by side without intervening glial processes.

Key words: neurotransmitter transport; glutamate uptake; protein purification; astroglia; cerebellum; hippocampus
1994; Maki et al., 1994; Tong and Jahr, 1994; Takahashi et al., 1996; Diamond and Jahr, 1997; Otis et al., 1997). Furthermore, astroglial anion-potentiated glutamate transporter currents are activated in $<1 \mathrm{msec}$ after release of glutamate (Bergles and Jahr, 1997; Bergles et al., 1997). Rusakov and Kullmann (1998) have performed kinetic simulations of the glutamate diffusion, and they used a range $(0-0.5 \mathrm{~mm})$ of values for the average glutamate transporter density because good data were lacking. Using the highest values they predicted that the transporters rapidly reduce the extrasynaptic glutamate concentration after the first millisecond and that interaction with the transporters slows down the diffusion of glutamate away from the site of release.

The densities of the glutamate transporters have been estimated electrophysiologically (Takahashi et al., 1996; Bergles and Jahr, 1997; Otis et al., 1997), but these data do not discriminate precisely between the individual transporter subtypes. In addition, the data are from immature animals, whereas the transporter densities are known to change dramatically during the development of the brain (Furuta et al., 1997; Ullensvang et al., 1997). Furthermore, biochemical uptake activity measurements have insufficient anatomical resolution and are likely to underestimate the true $V_{\max }$ value. Transport activity measurements are further hampered by the lack of nontransportable high-affinity subtypespecific blockers.

For these reasons, determination of the concentrations of the individual glutamate transporter proteins is required to obtain information on the transporter densities in the mature brain and on the contributions of the individual transporter subtypes. We have measured the concentrations of GLAST and GLT in the hippocampus CA1 (stratum radiatum) and in the cerebellum (molecular layer) in absolute terms in adult rats. We have also 
measured the astroglial surface densities in the two regions to calculate the numbers of transporter molecules per square micrometer of membrane.

\section{MATERIALS AND METHODS}

Antibodies. Antipeptide antibodies against GLT and GLAST were prepared as described (Lehre et al., 1995). The peptides representing parts of GLAST and GLT are referred to by capital letters "A" and "B," respectively, followed by numbers indicating the corresponding amino acid residues in the sequences (given in parentheses). The sequences refer to the rat sequences (Pines et al., 1992; Storck et al., 1992): A522-541 (PYQLIAQDNEPEKPVADSET), B12-26 (KQVEVRMHDSHLSSE), and B493-508 (YHLSKSELDTIDSQHR). The corresponding anti-peptide antibodies are referred to as anti-A522 (rabbit 68488), anti-B12 (rabbit 68518), and anti-B493 (rabbit 84912).

Animals. Adult male Wistar rats from Møllegaard Hansen (Lille Skensved, Denmark) were kept in the animal facility at the Institute of Basic Medical Sciences. All handling of animals was according to European regulations and was under veterinary supervision. The rats were killed by stunning and decapitation. The rat used for the estimation of surface densities and the rats in groups $\mathrm{C}$ and $\mathrm{D}$ in Table 1 were 7-8 weeks old.

Covalent immobilization of antibodies to protein A-Sepharose. Incubations were performed at room temperature if not stated otherwise. Antibodies to GLT (anti-B493) or GLAST (anti-A522) were covalently immobilized on protein A-Sepharose essentially as described (Danbolt et al., 1992) using $25 \mathrm{~mm}$ dimethylsuberimidate in $0.2 \mathrm{~m}$ triethanolamine$\mathrm{HCl}$ at $\mathrm{pH}$ 8.3. Noncovalently attached antibodies were removed by washing with $0.2 \mathrm{M}$ sodium citrate, $\mathrm{pH} 3.7$.

Immunoaffinity purification of GLT and GLAST. For each purification experiment, four forebrains $(\sim 550 \mathrm{mg}$ protein $)$ or eight cerebella $(\sim 240$ $\mathrm{mg}$ protein) freshly dissected from Wistar rats were homogenized in ice-cold solubilization buffer ( $2 \%$ cholate, 6 mM EDTA, $1 \mathrm{~mm}$ PMSF, $0.03 \% \mathrm{NaN}_{3}, 60 \mathrm{~mm} \mathrm{NaPi}, \mathrm{pH} \mathrm{7.4}$, and ammonium sulfate to $10 \%$ saturation) in a total volume of $32 \mathrm{ml}$. The homogenate was incubated $\left(10 \mathrm{~min}\right.$ on ice) and centrifuged $\left(39,000 \times g, 20 \mathrm{~min}, 4^{\circ} \mathrm{C}\right)$. The supernatant was mixed with $128 \mathrm{ml}$ buffer $(1.05 \%$ cholate, 6 mM EDTA, $94 \mathrm{~mm}$ $\left.\mathrm{NaCl}, 75 \mathrm{~mm} \mathrm{NaPi}, \mathrm{pH} 7.4,4^{\circ} \mathrm{C}\right)$, and incubated end-over-end $(60 \mathrm{~min}$, $4^{\circ} \mathrm{C}$ ) with the covalently immobilized antibodies (see above). The gel was washed $\left(3 \times 6 \mathrm{~min}, 4^{\circ} \mathrm{C}\right)$ with buffer $(0.3 \mathrm{M} \mathrm{NaCl}, 20 \mathrm{~mm}$ CHAPS, $40 \mathrm{~mm}$ $\mathrm{NaPi}, \mathrm{pH} 7.4)$, and the bound proteins were eluted $\left(2 \times 5 \mathrm{~min}, 4^{\circ} \mathrm{C}\right)$ with low-pH buffer $(0.15 \quad \mathrm{M} \quad \mathrm{NaCl}, 20 \mathrm{~mm}$ 3-[(3-cholamidopropyl)dimethylammonio]-1-propanesulphonate (CHAPS), $0.2 \mathrm{M}$ glycine- $\mathrm{HCl}, \mathrm{pH} 2.5$ ). The eluate was immediately neutralized with $2 \mathrm{M}$ Tris-HCl, pH 9. Dithiothreitol (50 mM), EDTA (5 mM), and PMSF (1 $\mathrm{mm}$ ) and $10 \mu \mathrm{l}$ of phenol red concentrate (as low molecular mass marker) were added. The solution was desalted on a $35 \mathrm{ml}$ Sephadex G-50 Fine column and concentrated on a $0.5 \mathrm{ml}$ DEAE-cellulose column coupled in series. The columns were equilibrated $\left(\right.$ at $\left.4^{\circ} \mathrm{C}\right)$ with degassed buffer [30 mM dithiothreitol, 20 mM CHAPS, $10 \mathrm{~mm} \mathrm{NaPi}$ (pH 7.4 for GLT, pH 7.8 for GLAST)]. The DEAE-cellulose column was washed (5 min) with 7.5 $\mathrm{ml}$ of the same buffer without dithiothreitol, and the protein was eluted ( $2 \mathrm{~min}$ ) with $1 \mathrm{ml}$ of $50 \mathrm{~mm} \mathrm{NaPi}$ with $0.2 \mathrm{M} \mathrm{NaCl}$ and $20 \mathrm{~mm}$ CHAPS. An aliquot of the eluate (destined for SDS-PAGE) was mixed with SDS sample buffer (Laemmli, 1970) containing $50 \mathrm{~mm}$ dithiothreitol and frozen. The rest of the eluate (for protein measurement) was frozen without additions. Because the conversion of immunoreactivities to micrograms of protein is dependent on the amounts of transporter protein in the standards, protein was determined both with the assay of Lowry (Lowry et al., 1951) and with the bicinchoninic acid assay (Smith et al., 1985). The values obtained were very similar (data not shown). Bovine serum albumin was used as standard.

The purity of the isolated protein was analyzed by SDS-PAGE (Laemmli, 1970) followed by staining with Coomassie brilliant blue or silver (Danbolt et al., 1990). The formation of SDS-insoluble higher molecular mass aggregates was largely avoided, although bands representing dimers are seen in the lanes loaded with the largest amounts of protein. No detectable amounts of $\mathrm{IgG}$ were leaking from the affinity column. As shown in Figure $1 B$, the IgG heavy chains gave rise to a band just below that of GLAST. This band was not present in the purified preparations (Fig. 1B, lane 3). Because the immunoaffinity isolation method is expensive with regard to antibodies, the antigen was always added in excess to ensure saturation of the antibodies. Under these conditions, $1 \mathrm{ml}$ of gel containing $1 \mathrm{mg}$ of immobilized antibodies gave $\sim 200 \mu \mathrm{g}$ of transporter protein after the final purification step. The calculations assume that the proteins were $90 \%$ pure.

Quantitative immunoblotting. The blotting was performed as described (Towbin et al., 1979; Levy et al., 1995). The tissue was dissolved in SDS. (SDS solubilizes brain tissue completely. It goes into a clear solution. Thus, the SDS extracts contained all tissue components.) After protein determination, the extracts were subjected to SDS-PAGE and blotted onto nitrocellulose membranes. The gels (Laemmli, 1970; Levy et al., 1995 ) were $0.75 \mathrm{~mm}$ thick, $14 \mathrm{~cm}$ wide, and $11 \mathrm{~cm}$ long and consisted of 7.5\% acrylamide. Each gel had 20 lanes. Known amounts of the purified GLT or GLAST proteins were used as standard. The tissue homogenates were prepared from whole hippocampus, whole cerebellum, microdissected stratum radiatum of hippocampus (subfield CA1, $\sim 4 \mathrm{~mm}$ from the temporal pole), and microdissected molecular layer of cerebellar vermis. The glial surface density (see below) was measured in the molecular layer of lobulus 6 only, whereas the tissue used for the quantification of transporter protein was collected from the molecular layer of all lobules. This was done to obtain enough protein without using an exceedingly large number of rats, and because in contrast to EAAT4, GLAST and GLT are evenly distributed in the molecular layer (Lehre et al., 1995; Dehnes et al., 1998). Differing amounts of standard and sample proteins were applied on each gel to verify signal linearity.

The immunolabeling of the blots was performed as described (Levy et al., 1995; Ullensvang et al., 1997). Briefly, the protein blots were blocked with gelatin, incubated (overnight) with antibody (anti-B12, $0.2 \mu \mathrm{g} / \mathrm{ml}$; anti-B493, $0.2 \mu \mathrm{g} / \mathrm{ml}$; anti-A522, $0.2 \mu \mathrm{g} / \mathrm{ml}$ ), washed, reblocked, incubated $(90 \mathrm{~min})$ with iodinated protein A $(600-2000 \mathrm{cpm} / \mu \mathrm{l})$, washed, dried, and mounted on transparent acetate sheets. Then the blots were autoradiographed with $\mathrm{x}$-ray film. The films were developed, put behind the transparent acetate sheets (on which the blots were mounted), and aligned with the nitrocellulose blots (Ullensvang et al., 1997). The nitrocellulose-film sandwiches were put on a glass plate illuminated from behind in a dark room so that the labeling on the films could be seen through the blots. The bands were cut out from the blots, and the radioactivity was determined. The background was determined on nitrocellulose membrane pieces of the same size, cut out from the blots below the labeled bands.

Whether anti-B12 or anti-B493 antibodies were used to detect GLT on the immunoblots did not seem to matter (data not shown), suggesting that any variable mRNA splicing does not significantly affect the amounts of these epitopes. The results shown from the immunoblotting are based on anti-B12 (whereas anti-B493 has been used for the purification).

Protein measurement. Protein was determined in purified protein and homogenates as described (Lowry et al., 1951) using bovine serum albumin as standard. To block the CHAPS interference with the color reaction, SDS $(50 \mathrm{mg} / \mathrm{ml})$ was added. SDS, CHAPS, buffer ions, and salt were added to give equal concentrations in samples and standards. The protein concentrations in several of the samples were also measured with the bicinchoninic acid assay (Smith et al., 1985), with bovine serum albumin as standard using a kit from Pierce (Rockford, IL). The results obtained with the two protein assays were very similar both in the crude tissue extracts and in the purified preparations of transporter proteins. The average values were used.

Estimation of glial surface density. This was performed in the stratum radiatum of hippocampus (subfield CA1) $\sim 4 \mathrm{~mm}$ from the temporal pole and in the stratum moleculare in vermis of cerebellum (lobulus 6).

One rat was perfusion-fixed (Lehre et al., 1995) with a mixture of $2.5 \%$ glutaraldehyde and $1 \%$ freshly depolymerized paraformaldehyde in 0.1 $\mathrm{M} \mathrm{NaPi}$. Pieces of fixed tissue were embedded in Durcupan as described (Lehre et al., 1995). Serial sections were cut following the vertical sectioning method of Baddeley et al. (1986) at 60-90 nm with a diamond knife and collected on nickel grids with a $2 \times 1 \mathrm{~mm}$ slot covered by a formvar/carbon film. The sections were treated for $2 \mathrm{sec}$ with xylene vapor, contrasted with uranyl acetate and lead citrate, and observed in a Phillips CM10 electron microscope. Pictures were taken from the corresponding parts of five to six sections in series at 4600 or $6300 \times$ primary magnification and printed at a final magnification of 40,000 or $55,000 \times$.

On each picture, tissue components were identified according to Peters et al. (1991) and Palay and Chan-Palay (1974). Photographs from serial sections were obtained because it is not always possible to identify all of the cellular processes in a single picture and because this study required identification of all astrocytic processes to obtain a measure for the total astroglial cell surface. The serial photographs greatly helped the identification because the individual components could be followed through several sections. After glial cell membranes were identified, the surface 
densities were calculated using a stereological method (Baddeley et al., 1986) based on an overlay screen with points and $2 \mathrm{~cm}$ cycloid arcs. The surface densities were estimated according to the formula $S(V)=2 \times$ $(p / l) \times(I / P)$, where $p / l$ is the ratio of test points to test curve length on the overlay screen and $I / P$ is the ratio of test curve intersection counts to point counts. For hippocampus, the tangent to the septotemporal axis $\sim 4$ $\mathrm{mm}$ from the temporal pole was chosen as vertical axis. For cerebellum, the direction of the parallel fibers was chosen as vertical axis. Because the distribution of the fine astroglial processes appears relatively isotropic (Spacek, 1985), only two sectioning angles perpendicular to each other were used. Surface densities were estimated from each angle separately so that the results from the two angles could be compared, and the mean value was calculated. For hippocampus, the two sectioning angles from one rat gave $2 \times(5.48 / \mu \mathrm{m}) \times(48 / 381)=1.38 \mu \mathrm{m}^{2} / \mu \mathrm{m}^{3}$ and $2 \times$ $(4.00 / \mu \mathrm{m}) \times(122 / 732)=1.33 \mu \mathrm{m}^{2} / \mu \mathrm{m}^{3}$, respectively, from a total of 234 $\mu \mathrm{m}^{2}$ electron micrographs. For cerebellum from the same rat, the two angles gave $2 \times(5.48 / \mu \mathrm{m}) \times(149 / 508)=3.21 \mu \mathrm{m}^{2} / \mu \mathrm{m}^{3}$ and $2 \times$ $(5.48 / \mu \mathrm{m}) \times(305 / 780)=4.29 \mu \mathrm{m}^{2} / \mu \mathrm{m}^{3}$, respectively, from $171 \mu \mathrm{m}^{2}$ electron micrographs.

Estimation of volume changes during tissue processing and sectioning. The tissue volume after perfusion fixation was taken as reference volume. This was done both because of the difficulty (Harvey and Napper, 1991) in determining changes in tissue volume during tissue fixation for electron microscopy and because the volume changes during the perfusion fixation appeared to be small enough to be ignored in the present study.

Less than $3 \%$ change in lengths, corresponding to $<10 \%$ change in volume, was observed in fixed tissue blocks from cortex cerebri during osmication, dehydration, and embedding in Durcupan. Sectioning resulted in a $10 \%$ compression of the side oriented perpendicular to the knife edge. Thus, the $10 \%$ compression roughly counterbalanced the volume increase during embedding reported previously (Harvey and Napper, 1991). Xylene vapor treatment (removed wrinkles, but) did not change the lengths significantly. Magnification $(4600$ and $6300 \times)$ was within 2\%, according to the Agar Scientific S106 magnification calibration grid photographed in the electron microscope.

\section{RESULTS}

\section{Quantification of GLT and GLAST in fresh tissue}

GLT and GLAST were quantified (by immunoblotting) by comparing the immunoreactivity (per micrograms of protein) of whole tissue solubilized in SDS with the immunoreactivity (per micrograms of protein) of purified protein standards. To obtain sufficient amounts of standard GLT and GLAST, an immunoaffinity purification procedure was developed (see Materials and Methods), and highly purified transporter protein was obtained (Fig. 1). The immunoreactivities in the whole-tissue protein extracts were very high (Table 1). GLAST and GLT represent as much as $0.32 \pm 0.01$ and $1.3 \pm 0.03 \%$ of total tissue protein in the hippocampal (CA1) stratum radiatum, and $1.8 \pm 0.02$ and $0.30 \pm$ $0.01 \%$ in the cerebellar molecular layer, respectively. The concentrations of GLAST and GLT in whole forebrain (minus hypophysis and olfactory bulbs) homogenates were $\sim 85$ and $70 \%$, respectively, of the concentrations in the hippocampus (data not shown), corresponding to approximately 0.2 and $0.8 \%$ of the total tissue protein.

From Table 2, it can be calculated that the total number of GLAST and GLT molecules in the stratum radiatum (hippocampus) and the total number of GLAST, GLT, and EAAT4 molecules in the molecular layer (cerebellum) are 15,000 and 23,000 per $\mu \mathrm{m}^{3}$ tissue in the two regions, respectively.

\section{Estimation of glial surface density}

For hippocampus stratum radiatum CA1, the mean estimated astroglial surface density was $1.4 \mu \mathrm{m}^{2} / \mu \mathrm{m}^{3}\left(\mathrm{~m}^{2} / \mathrm{cm}^{3}\right)$. This value appears reasonable when compared with the astroglial surface density in the rat visual cortex, which has been estimated (Jones and Greenough, 1996) to be in the range of $1.34-1.64 \mu \mathrm{m}^{2} / \mu \mathrm{m}^{3}$

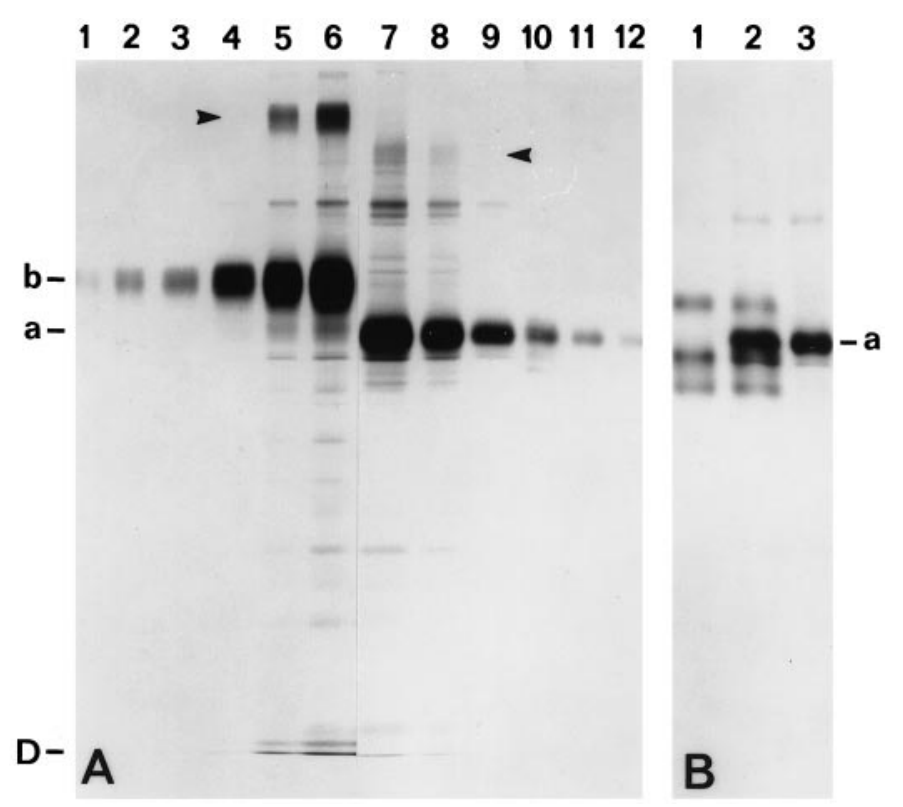

Figure 1. Demonstration of the purity of the isolated glutamate transporter proteins and the lack of contamination with $\operatorname{IgG}$. A, Purified GLT and GLAST proteins were separated by SDS-PAGE (10\% acrylamide) and visualized by silver staining as described in Materials and Methods. Lanes 1-6 contain 30, 60, 100, 300, 600, and $1000 \mathrm{ng}$ of GLT, respectively, whereas lanes $7-12$ contain 1000, 600, 300, 100, 60, and $30 \mathrm{ng}$ of GLAST, respectively. The positions of monomer $(a, b)$ and dimer (arrowheads) bands of GLAST $(a)$ and GLT $(b)$ are marked. $B$, Purified GLAST protein and preimmune IgG (rabbit 68488) were run on $10 \%$ SDS-PAGE and stained with silver. The IgG has been treated with the low $\mathrm{pH}$ elution buffer and dithiothreitol, like the GLAST protein during isolation (see Materials and Methods). Lane 1, IgG alone (500 ng); lane 2, IgG and GLAST (500 and $300 \mathrm{ng}$, respectively); lane 3, GLAST alone (300 ng).

depending on the cortical layer and the complexity of the environment the rats were raised in.

For the molecular layer of cerebellum (vermis, lobulus 6), the mean surface density of astroglia (mainly Bergmann glia) was 3.8 $\mu \mathrm{m}^{2} / \mu \mathrm{m}^{3}$. This finding of a 2.7 times higher glial surface density in cerebellum than in hippocampus is also reasonable as judged from the available literature. Spacek (1985) found that $74 \%$ of the circumference of longitudinal dendritic spine profiles in the cerebellar cortex was covered by glial sheaths (i.e., all of the surface not contacted by the afferent axon terminals), whereas glial sheaths covered only $29 \%$ of spines in the visual cortex of the mouse. Furthermore, the surface density of Purkinje cell spines (Dehnes et al., 1998), which was estimated in the present material, was virtually identical to the value that could be calculated from previously published data on the number of Purkinje cells and the number of spines per cell (Harvey and Napper, 1988, 1991; Napper and Harvey, 1988).

The total area of all cell membranes was estimated to be $\sim 14$ $\mu \mathrm{m}^{2} / \mu \mathrm{m}^{3}$ in both regions. This is in excellent agreement with Rusakov and Kullmann (1998) who arrived at $14.2 \mu \mathrm{m}^{2} / \mu \mathrm{m}^{3}$ in the stratum oriens of the adult rat hippocampus CA1.

\section{Densities of GLT and GLAST in glial cell membranes}

In a previous study (Chaudhry et al., 1995) of ultrastructural distributions of GLT and GLAST in hippocampus and cerebellum, virtually all of the immunoreactivity appeared to be related to the astrocytic plasma membranes. Furthermore, all astrocytes (in the two regions) appeared to express these proteins, and no 


\begin{tabular}{|c|c|c|c|c|c|}
\hline & \multicolumn{2}{|c|}{ Hippocampus } & \multicolumn{3}{|l|}{ Cerebellum } \\
\hline & Whole & $\begin{array}{l}\text { CA1 Stratum } \\
\text { radiatum }\end{array}$ & Whole & Whole & Stratum moleculare \\
\hline GLAST & A & $\mathrm{C}$ & A & B & $\mathrm{D}$ \\
\hline 1 & $0.25 \pm 0.02$ & $0.40 \pm 0.01$ & $0.81 \pm 0.03$ & $1.0 \pm 0.04$ & $2.3 \pm 0.05$ \\
\hline 2 & $0.13 \pm 0.01$ & $0.21 \pm 0.004$ & $0.47 \pm 0.04$ & $0.53 \pm 0.02$ & $1.3 \pm 0.03$ \\
\hline 3 & $0.24 \pm 0.01$ & $0.36 \pm 0.01$ & $0.70 \pm 0.05$ & $0.79 \pm 0.03$ & $2.0 \pm 0.04$ \\
\hline 4 & & & & $0.64 \pm 0.03$ & $1.6 \pm 0.03$ \\
\hline Mean & $0.21 \pm 0.02$ & $0.32 \pm 0.01$ & $0.66 \pm 0.04$ & $0.74 \pm 0.03$ & $1.8 \pm 0.02$ \\
\hline GLT & B & $\mathrm{C}$ & & B & $\mathrm{D}$ \\
\hline 1 & $1.3 \pm 0.03$ & $1.3 \pm 0.03$ & & $0.27 \pm 0.005$ & $0.34 \pm 0.004$ \\
\hline 2 & $1.2 \pm 0.02$ & $1.3 \pm 0.04$ & & $0.24 \pm 0.005$ & $0.30 \pm 0.01$ \\
\hline 3 & $1.1 \pm 0.03$ & $1.3 \pm 0.04$ & & & $0.31 \pm 0.01$ \\
\hline 4 SDS & $1.2 \pm 0.02$ & $1.2 \pm 0.03$ & & $0.22 \pm 0.004$ & $0.28 \pm 0.003$ \\
\hline 5 & $1.1 \pm 0.02$ & $1.1 \pm 0.03$ & & $0.22 \pm 0.003$ & $0.27 \pm 0.001$ \\
\hline Mean & $1.2 \pm 0.02$ & $1.3 \pm 0.03$ & & $0.24 \pm 0.004$ & $0.30 \pm 0.01$ \\
\hline
\end{tabular}

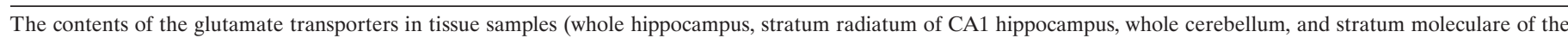

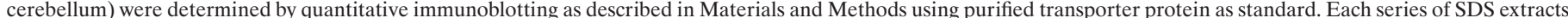

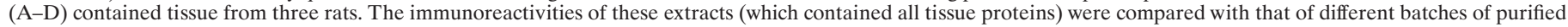

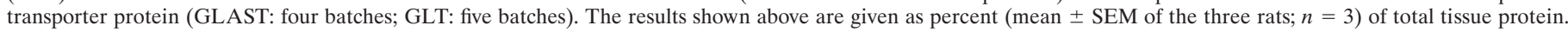
The GLT protein was isolated from the entire forebrain solubilized with cholate (or SDS as indicated).

concentration differences were noted between cell bodies and processes. For the calculations (Table 2) it is therefore assumed that all of the GLAST and GLT proteins are evenly distributed in the astrocytic plasma membranes.

It should be noted, however, that the transporter concentrations are lower (but not zero) in the parts of the astrocytic membranes facing other astrocytes, cell bodies, large dendrites, pia mater, and vascular epithelium than in the parts facing neuronal processes in the neuropil (Chaudhry et al., 1995). To decide how much these differences affect the calculations (Table 2), we estimated the surface density of astrocytic membranes contacting other astrocytic membranes in the cerebellar molecular layer and arrived at $0.46 \mu \mathrm{m}^{2} / \mu \mathrm{m}^{3}$, or $\sim 12 \%$ of the total astrocytic surface area. The corresponding value for the stratum radiatum was not determined because astrocyte-to-astrocyte contacts are seen less frequently here. The surface density of astrocytic membranes facing large dendrites in the molecular layer was $0.13 \mu \mathrm{m}^{2} / \mu \mathrm{m}^{3}$, or $\sim 3 \%$ of the total. The percentages of the astrocytic area contacting vascular epithelium or pia mater were not determined either, but they appeared to be orders of magnitude smaller. Thus, ignoring the differences in transporter densities between neuropil- and non-neuropil-facing parts of the astrocytic membrane introduces an error that is $<10 \%$ in the cerebellum and even less in the hippocampus.

\section{DISCUSSION}

\section{The total tissue concentration of glutamate transporters}

Available data (Haugeto et al., 1996; Rothstein et al., 1996) suggest that GLT and GLAST are the quantitatively dominating glutamate transporters and that the contribution of EAAC to the total uptake is small. This conclusion is also in line with the observations that genetically EAAC-deficient mice (Peghini et al., 1997) do not have elevated levels of extracellular glutamate and do not develop neurodegeneration. In contrast, mice deficient in GLT develop both epilepsy and neurodegeneration (Tanaka et al., 1997). The concentration of EAAT4 is quite high in the cerebellar cortex (Table 2) but very low in the forebrain (Dehnes et al., 1998), whereas EAAT5 seems to be a retinal protein (Arriza et al., 1997). The astroglial localization of GLT and GLAST (Levy et al., 1993; Lehre et al., 1995) is in agreement with the notion that astrocytes have the largest glutamate uptake activity (Schousboe, 1981). Postsynaptic uptake may be of functional significance in the cerebellum at postnatal day 12 (Takahashi et al., 1996), but because the total transporter densities as well as the relative contribution of the glial transporters to the total uptake are much higher in the adult (Furuta et al., 1997; Ullensvang et al., 1997), we do not know how important postsynaptic uptake is in the adult cerebellum. Nevertheless, it is likely that postsynaptic uptake plays a functional role in the parts of adult cerebellum with high levels of EAAT4 (see Table 2 legend). The importance of EAAC for postsynaptic uptake is unclear because of the low levels and lack of quantitative data.

The glutamate uptake in nerve endings (Divac et al., 1977) is still a puzzle because the nerve terminal glutamate transporter has not yet been identified by molecular cloning. Still, its existence is difficult to dispute (Gundersen et al., 1993). Like GLT (Arriza et al., 1994) it appears to be sensitive to dihydrokainic acid, and it is legitimate to speculate about whether it is a variant of GLT (Eliasof et al., 1998) in accordance with the apparent presence of GLT mRNA in some neurons (Torp et al., 1994, 1997). Recent data (Asztely et al., 1997) based on hippocampal slices from 4- to 5-week-old guinea pigs suggest that dihydrokainate-sensitive transporters are of great physiological significance in reducing cross-talk between neighboring synapses, but at present, we cannot tell whether this is mainly attributable to astrocytic GLT or to the elusive nerve terminal transporter.

Thus, assuming that the concentration of the nerve terminal transporter is low, the total concentrations of glutamate transporters in the hippocampus stratum radiatum and in the cerebellar molecular layer are almost 30 and $40 \mu \mathrm{M}$, respectively (Table 2). The effective concentrations, however, are higher because these proteins are accessible from the extracellular fluid and are mostly associated with astrocytes (see below and Table 2). The 


\begin{tabular}{|c|c|c|c|c|c|}
\hline & $\begin{array}{l}\mathrm{mg} / \mathrm{gm} \\
\text { tissue }\end{array}$ & $\mu \mathrm{M}$ & $\begin{array}{l}\text { Molecules } \\
\text { per } \mu \mathrm{m}^{3}\end{array}$ & $\begin{array}{l}\text { Membrane } \\
\mu \mathrm{m}^{2} / \mu \mathrm{m}^{3}\end{array}$ & $\begin{array}{l}\text { Molecule } \\
\text { per } \mu \mathrm{m}^{2}\end{array}$ \\
\hline \multicolumn{6}{|c|}{$\begin{array}{l}\text { Stratum radiatum, } \\
\text { hippocampus CA1 }\end{array}$} \\
\hline GLAST & 0.32 & 5.3 & 3200 & $1.4^{a}$ & 2300 \\
\hline GLT & 1.3 & 20 & 12000 & $1.4^{a}$ & 8500 \\
\hline \multicolumn{6}{|c|}{$\begin{array}{l}\text { Stratum moleculare, } \\
\text { cerebellum }\end{array}$} \\
\hline GLAST & 1.8 & 29 & 18000 & $3.8^{a}$ & 4700 \\
\hline GLT & 0.30 & 4.7 & 2800 & $3.8^{a}$ & 740 \\
\hline $\mathrm{EAAT}^{b}$ & 0.2 & 3.2 & 1900 & $1.1^{c}$ & $1800^{c}$ \\
\hline
\end{tabular}

$\overline{\text { Our data (Table 1) have been used to calculate the GLAST and GLT concentrations }}$ both per volume of tissue and per cell membrane area. For the calculations presented in this table, it is assumed that brain tissue contains $\sim 97.8 \mathrm{gm} / \mathrm{kg}$ protein (Lowry et al., 1954) and has a density of $1.05 \mathrm{gm} / \mathrm{cm}^{3}$ (Lowry, 1953) (i.e. $1 \mu \mathrm{m}^{3}$ contains $\sim 10^{-13}$ gm of protein) and that the molecular masses of the polypeptide parts of GLAST (Storck et al., 1992) and GLT (Pines et al., 1992) are 61 and $64 \mathrm{kDa}$, respectively. The total plasma membrane density was $\sim 14 \mu \mathrm{m}^{2} / \mu \mathrm{m}^{3}$ in both regions. ${ }^{a}$ Astroglial membrane. The protein is almost exclusively present in astrocytic membranes (Chaudhry et al., 1995; Lehre et al., 1995).

${ }^{b}$ Data from Dehnes et al. (1998).

${ }^{c}$ Purkinje cell spine membrane. NB: It must be kept in mind that these are average values (Dehnes et al., 1998). First, EAAT4 is exclusively expressed in Purkinje cells but is unevenly distributed in the membranes of the individual Purkinje cell. The highest concentrations are found in the parts of the membrane facing glia. Second, EAAT4 is also unevenly distributed in the molecular layer, and it is expressed at different densities in different parasagittal zones. The values given here are based on a large part of the molecular layer (including both weakly and strongly expressing zones) and represent the average densities in the Purkinje cell spine membrane facing glia. The densities in the weakly and strongly expressing zones are not known but are assumed (Dehnes et al., 1998) to be approximately two times lower or higher, respectively, than the average value.

extracellular fluid represents $0.12-0.22 \%$ of the tissue volume in the normal adult rat hippocampus (McBain et al., 1990; Nicholson and Syková, 1998; Rusakov and Kullmann, 1998) and about the same in the cerebellar molecular layer (Nicholson and Syková, 1998). This implies average effective concentrations of $0.14-0.25$ and $0.18-0.33 \mathrm{~mm}$, respectively, depending on the extracellular volume. From the data presented here (see Results and Table 2), it can be calculated that the fraction of the extracellular space being enclosed between one astroglial and one nonastroglial membrane is $\sim 20$ and $50 \%$ in the hippocampus (CA1 stratum radiatum) and cerebellum (molecular layer), respectively. Thus, the effective concentrations of the transporters in the vicinity of astrocytes facing neuropil are on the order of 0.7-1.3 and 0.36-0.66 $\mathrm{mm}$ in the two regions, respectively, depending on the extracellular volume.

\section{Comparison of the present findings with recent electrophysiological data}

It should be kept in mind that the numbers presented here represent the total number of glutamate transporter molecules and do not give information on transport activity. The activities of the proteins are subject to regulation (for review, see Danbolt et al., 1998), and the percentages of the transporters in the various activity states are unknown. Furthermore, transporter molecules (with the expected molecular mass) both in plasma membranes and in intracellular membranes are included in our measurements; however, the latter is minor compared with the former (Chaudhry et al., 1995; Dehnes et al., 1998). Nevertheless, our data are in good agreement with recent electrophysiological observations. Bergles and Jahr (1997) estimated the density of glutamate transporters to be $>2500 \mu \mathrm{m}^{-2}$ in the somatic mem- brane of astrocytes from 14-d-old rats (hippocampus CA1 stratum radiatum). With the caveat that the glial surface density is unknown at this age, this value is in good agreement with our value of $10,800 \mathrm{\mu m}^{-2}$ in adult rats (Table 2: $8500 \mathrm{GLT}+2300$ GLAST). First, the uptake activity at $60 \mathrm{~d}$ (adult) is 3-5 times higher than that at $14 \mathrm{~d}$ (Furuta et al., 1997; Ullensvang et al., 1997). Second, no differences in GLT and GLAST densities have been detected between astroglial bodies and processes (Chaudhry et al., 1995). Furthermore, the glial membranes also contain some EAAC molecules (Conti et al., 1998), although this value is probably low, as explained above, compared with the values for GLT and GLAST. Takahashi and co-workers (1996) estimated the transporter densities on Purkinje cells from 12-d-old rats to be between 1315 and 13,150, depending on which transporter (EAAT4 or EAAC) is the more abundant. Otis and coworkers (1997) predicted that a postsynaptic transporter (presumably EAAT4) binds at least 880 glutamate molecules per release site (implying that the number of transporters must be higher because saturation cannot be expected).

\section{Binding and transport capacities compared with release capacity}

Stevens and Tsujimoto (1995) estimated that each average central synapse has approximately 20 release sites, each of which needs $\sim 10 \mathrm{sec}$ to refill. Thus, each terminal can release a total of approximately 20 vesicles within a $10 \mathrm{sec}$ period. This implies a maximum average release rate of two vesicles/sec. The average densities of glutamatergic synapses in the stratum radiatum of hippocampus CA1 and the cerebellar molecular layer are 0.9-1.3 $\mu \mathrm{m}^{-3}$ (Woolley and McEwen, 1992) and $0.8 \mu \mathrm{m}^{-3}$ (Harvey and Napper, 1991), respectively. If one synaptic vesicle contains 4000-5000 molecules (Clements, 1996; Barbour and Häusser, 1997), it follows that the binding capacity of the known transporters $\left(15,000\right.$ and $\left.23,000 \mu \mathrm{m}^{-3}\right)$ is significant compared with the release capacity. A transporter cycling time of $70 \mathrm{msec}$ implies that the theoretical $V_{\max }$ of 20,000 glutamate transporters is 290,000 glutamate molecules/sec.

\section{Will synaptic spill-over cause cross-talk?}

In an extreme situation with the simultaneous release of many vesicles, it is clear that the transporters cannot absorb all of the released glutamate without going through several transport cycles, but in moderate cases with only a few vesicles released each second, the concentration of glutamate reaching a neighboring synapse will depend on the geometry of the extracellular space with its diff usion barriers and on the location of the transporters. Because most of the transporters are on astrocytes (GLAST and GLT as well as some of the EAAC) or on neuronal membranes facing astrocytes (EAAT4), the question of whether the transporters contribute significantly to preventing glutamate from reaching neighboring synapses is more or less the same as asking where the astrocytic processes are in relation to the release sites and the diffusion barriers (unless the nerve terminal glutamate transporter or novel postsynaptic transporters, as explained above, contribute significantly).

In the cerebellum, glutamatergic synapses are often almost completely ensheathed by glia (Fig. $2 B$ ). Neighboring synapses are usually separated by astrocytic processes, which express high densities of GLAST and GLT (Table 2). The situation is very different in the stratum radiatum of hippocampus CA1. Although most of the spines are contacted by astrocytes, only a fraction of the spine surface is covered with glia. This is illustrated in Figure 

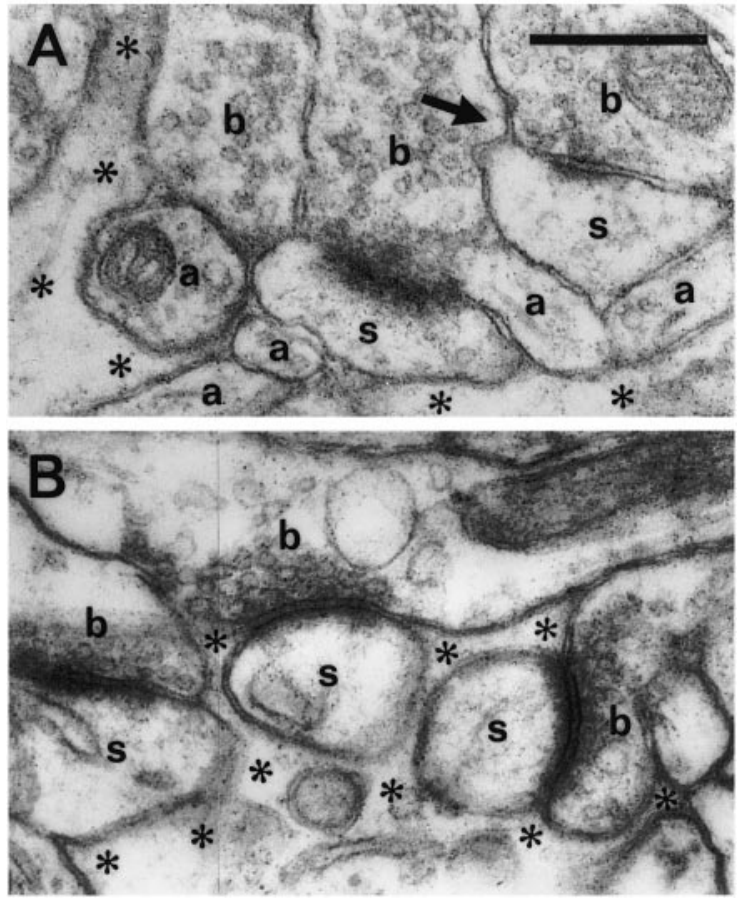

Figure 2. Electron micrographs of neighboring synapses in stratum radiatum of the hippocampus CA1 $(A)$ and of the cerebellar molecular layer $(B)$. The synapses shown have the typical morphology of glutamatergic synapses in the two regions: synapses with asymmetric postsynaptic specializations between boutons $(b)$ and spines $(s)$. Note that the (GLASTand GLT-expressing) glial processes (asterisks) in hippocampus $(A)$ surround the group of synapses and axons $(a)$, and that one of the boutons shown is in close contact with the neighboring synaptic cleft (arrow). In contrast, the three cerebellar synapses $(B)$ between parallel fibers and Purkinje cell spines are almost completely ensheathed and thereby separated from each other by (GLAST- and GLT-expressing) glial processes (asterisks). Scale bar, $400 \mathrm{~nm}$.

$2 A$, which also shows an example of two neighboring synapses in close proximity to each other without separating glial processes, a very common sight in this region. In cases such as that depicted in Figure $2 A$, the glutamate diffusing out of the synaptic cleft opposite to the glial process will not be hindered by the glial glutamate transporters on its way toward the cleft of the neighboring synapse. Thus, at these sites (on the short time scale) glutamate is inactivated by diff usion unless EAAC or novel transporters are present in high concentrations. Note that astroglial processes are close to the synaptic clefts in both regions, in agreement with the observed activation of glial transporter currents shortly after glutamate release (Bergles and Jahr, 1997; Bergles et al., 1997).

Although detailed three-dimensional models of the tissue would be valuable to simulate glutamate diffusion and inactivation, not even such models would give the complete picture because all of the structures are dynamic. Both the dendritic spines (Fifkova, 1985; Fischer et al., 1998) and astrocytic processes (Wenzel et al., 1991) are able to change their forms by contraction and distension. Furthermore, the glutamate transporter (Gegelashvilli et al., 1997) and receptor (Rao and Craig, 1997) densities are subject to various kinds of regulation.

In conclusion, glutamate transporters are present at sufficiently high average densities to support the notion (Tong and Jahr, 1994; Diamond and Jahr, 1997) that they can contribute to glutamate inactivation on the short time scale by binding rather than by transport. However, their importance in the control of extrasynaptic and intersynaptic glutamate diffusion is likely to vary considerably between different synapses because the transporters are predominantly associated with astrocytes and thereby not evenly distributed in the extracellular space. Mathematical models of the spatiotemporal transmitter profile after synaptic release should therefore take into account the localizations of astrocytic processes in relation to the transmitter release sites.

\section{REFERENCES}

Arriza JL, Fairman WA, Wadiche JI, Murdoch GH, Kavanaugh MP, Amara SG (1994) Functional comparisons of three glutamate transporter subtypes cloned from human motor cortex. J Neurosci 14:5559-5569.

Arriza JL, Eliasof S, Kavanaugh MP, Amara SG (1997) Excitatory amino acid transporter 5, a retinal glutamate transporter coupled to a chloride conductance. Proc Natl Acad Sci USA 94:4155-4160.

Asztely F, Erdemli G, Kullmann DM (1997) Extrasynaptic glutamate spillover in the hippocampus: dependence on temperature and the role of active glutamate uptake. Neuron 18:281-293.

Baddeley AJ, Gundersen HJG, Cruz-Orive LM (1986) Estimation of surface area from vertical sections. J Microsc 142:259-276.

Barbour B, Häusser M (1997) Intersynaptic diffusion of neurotransmitter. Trends Neurosci 20:377-384.

Barbour B, Keller BU, Llano I, Marty A (1994) Prolonged presence of glutamate during excitatory synaptic transmission to cerebellar Purkinje cells. Neuron 12:1331-1343.

Bergles DE, Jahr CE (1997) Synaptic activation of glutamate transporters in hippocampal astrocytes. Neuron 19:1297-1308.

Bergles DE, Dzubay JA, Jahr CE (1997) Glutamate transporter currents in bergmann glial cells follow the time course of extrasynaptic glutamate. Proc Natl Acad Sci USA 94:14821-14825.

Chaudhry FA, Lehre KP, Campagne MV, Ottersen OP, Danbolt NC, Storm-Mathisen J (1995) Glutamate transporters in glial plasma membranes: highly differentiated localizations revealed by quantitative ultrastructural immunocytochemistry. Neuron 15:711-720.

Clements JD (1996) Transmitter timecourse in the synaptic cleft: its role in central synaptic function. Trends Neurosci 19:163-171.

Conti F, Debiasi S, Minelli A, Rothstein JD, Melone M (1998) EAAC1, a high-affinity glutamate transporter, is localized to astrocytes and GABAergic neurons besides pyramidal cells in the rat cerebral cortex. Cereb Cortex 8:108-116.

Danbolt NC (1994) The high affinity uptake system for excitatory amino acids in the brain. Prog Neurobiol 44:377-396.

Danbolt NC, Pines G, Kanner BI (1990) Purification and reconstitution of the sodium- and potassium-coupled glutamate transport glycoprotein from rat brain. Biochemistry 29:6734-6740.

Danbolt NC, Storm-Mathisen J, Kanner BI (1992) A $\left[\mathrm{Na}^{+}+\mathrm{K}^{+}\right]$coupled $\mathrm{L}$-glutamate transporter purified from rat brain is located in glial cell processes. Neuroscience 51:295-310.

Danbolt NC, Chaudhry FA, Dehnes Y, Lehre KP, Levy LM, Ullensvang K, Storm-Mathisen J (1998) Properties and localization of glutamate transporters. Prog Brain Res 116:21-41.

Dehnes Y, Chaudhry FA, Ullensvang K, Lehre KP, Storm-Mathisen J, Danbolt NC (1998) The glutamate transporter EAAT4 in rat cerebellar Purkinje cells: a glutamate-gated chloride channel concentrated near the synapse in parts of the dendritic membrane facing astroglia. J Neurosci 18:3606-3619.

Diamond JS, Jahr CE (1997) Transporters buffer synaptically released glutamate on a submillisecond time scale. J Neurosci 17:4672-4687.

Divac I, Fonnum F, Storm-Mathisen J (1977) High affinity uptake of glutamate in terminals of corticostriatal axons. Nature 266:377-378.

Eliasof S, Arriza JL, Leighton BH, Kavanaugh MP (1998) Excitatory amino acid transporters of the salamander retina: identification, localization, and function. J Neurosci 18:698-712.

Fifkova E (1985) A possible mechanism of morphometric changes in dendritic spines induced by stimulation. Cell Mol Neurobiol 5:47-63.

Fischer M, Kaech S, Knutti D, Matus A (1998) Rapid actin-based plasticity in dendritic spines. Neuron 20:847-854.

Furuta A, Rothstein JD, Martin LJ (1997) Glutamate transporter protein subtypes are expressed differentially during rat CNS development. J Neurosci 17:8363-8375.

Gegelashvili G, Danbolt NC, Schousboe A (1997) Neuronal soluble fac- 
tors differentially regulate the expression of the GLT1 and GLAST glutamate transporters in cultured astroglia. J Neurochem 69:2612-2615.

Gundersen V, Danbolt NC, Ottersen OP, Storm-Mathisen J (1993) Demonstration of glutamate/aspartate uptake activity in nerve endings by use of antibodies recognizing exogenous D-aspartate. Neuroscience 57:97-111.

Harvey RJ, Napper RM (1988) Quantitative study of granule and Purkinje cells in the cerebellar cortex of the rat. J Comp Neurol 274:151-157.

Harvey RJ, Napper RM (1991) Quantitative studies on the mammalian cerebellum. Prog Neurobiol 36:437-463.

Haugeto $\varnothing$, Ullensvang K, Levy LM, Chaudhry FA, Honoré T, Nielsen M, Lehre KP, Danbolt NC (1996) Brain glutamate transporter proteins form homomultimers. J Biol Chem 271:27715-27722.

Holmes WR (1995) Modeling the effect of glutamate diffusion and uptake on NMDA and non-NMDA receptor saturation. Biophys J 69:1734-1747.

Jones TA, Greenough WT (1996) Ultrastructural evidence for increased contact between astrocytes and synapses in rats reared in a complex environment. Neurobiol Learn Mem 65:48-56.

Kleinle J, Vogt K, Luscher HR, Muller L, Senn W, Wyler K, Streit J (1996) Transmitter concentration profiles in the synaptic cleft: an analytical model of release and diffusion. Biophys J 71:2413-2426.

Laemmli UK (1970) Cleavage of structural proteins during the assembly of the head of bacteriophage T4. Nature 227:680-685.

Lehre KP, Levy LM, Ottersen OP, Storm-Mathisen J, Danbolt NC (1995) Differential expression of two glial glutamate transporters in the rat brain: quantitative and immunocytochemical observations. J Neurosci 15:1835-1853.

Levy LM, Lehre KP, Rolstad B, Danbolt NC (1993) A monoclonal antibody raised against an $\left[\mathrm{Na}^{+}+\mathrm{K}^{+}\right]$coupled L-glutamate transporter purified from rat brain confirms glial cell localization. FEBS Lett 317:79-84.

Levy LM, Lehre KP, Walaas SI, Storm-Mathisen J, Danbolt NC (1995) Down-regulation of glial glutamate transporters after glutamatergic denervation in the rat brain. Eur J Neurosci 7:2036-2041.

Lowry OH (1953) The quantitative histochemistry of the brain. J Histochem Cytochem 1:420-428.

Lowry OH, Rosebrough NJ, Farr AL, Randall RJ (1951) Protein measurement with the Folin phenol reagent. J Biol Chem 193:265-275.

Lowry OH, Roberts NR, Leiner KY, Wu ML, Farr AL, Albers RW (1954) The quantitative histochemistry of brain, III. Ammon's horn. J Biol Chem 207:39-49.

Maki R, Robinson MB, Dichter MA (1994) The glutamate uptake inhibitor L-trans-pyrrolidine-2,4-dicarboxylate depresses excitatory synaptic transmission via a presynaptic mechanism in cultured hippocampal neurons. J Neurosci 14:6754-6762.

McBain CJ, Traynelis SF, Dingledine R (1990) Regional variation of extracellular space in the hippocampus. Science 249:674-677.

Napper RM, Harvey RJ (1988) Quantitative study of the Purkinje cell dendritic spines in the rat cerebellum. J Comp Neurol 274:158-167.

Nicholson C, Syková E (1998) Extracellular space structure revealed by diff usion analysis. Trends Neurosci 21:207-215.

Otis TS, Wu YC, Trussell LO (1996) Delayed clearance of transmitter and the role of glutamate transporters at synapses with multiple release sites. J Neurosci 16:1634-1644.

Otis TS, Kavanaugh MP, Jahr CE (1997) Postsynaptic glutamate transport at the climbing fiber purkinje cell synapse. Science 277:1515-1518.

Palay SL, Chan-Palay V (1974) Cerebellar cortex: cytology and organization. New York: Springer.

Peghini P, Janzen J, Stoffel W (1997) Glutamate transporter EAAC-1deficient mice develop dicarboxylic aminoaciduria and behavioral abnormalities but no neurodegeneration. EMBO J 16:3822-3832.
Peters A, Palay SL, Webster HF (1991) The fine structure of the nervous system. Neurons and their supporting cells. New York: Oxford UP.

Pines G, Danbolt NC, Bjørås M, Zhang Y, Bendahan A, Eide L, Koepsell H, Storm-Mathisen J, Seeberg EK, Kanner BI (1992) Cloning and expression of a rat brain L-glutamate transporter. Nature 360:464-467.

Rao A, Craig AM (1997) Activity regulates the synaptic localization of the NMDA receptor in hippocampal neurons. Neuron 19:801-812.

Robinson MB, Dowd LA (1997) Heterogeneity and functional properties of subtypes of sodium-dependent glutamate transporters in the mammalian central nervous system. Adv Pharmacol 37:69-115.

Rothstein JD, Dykes-Hoberg M, Pardo CA, Bristol LA, Jin L, Kuncl RW, Kanai Y, Hediger MA, Wang Y, Schielke JP, Welty DF (1996) Knockout of glutamate transporters reveals a major role for astroglial transport in excitotoxicity and clearance of glutamate. Neuron 16:675-686.

Rusakov DA, Kullmann DM (1998) Extrasynaptic glutamate diffusion in the hippocampus: ultrastructural constraints, uptake, and receptor activation. J Neurosci 18:3158-3170.

Schousboe A (1981) Transport and metabolism of glutamate and GABA in neurons and glial cells. Int Rev Neurobiol 22:1-45.

Smith PK, Krohn RI, Hermanson GT, Mallia AK, Gartner FH, Provenzano MD, Fujimoto EK, Goeke NM, Olson BJ, Klenk DC (1985) Measurement of protein using bicinchoninic acid. Anal Biochem 150:76-85.

Spacek J (1985) Three-dimensional analysis of dendritic spines. III. Glial sheath. Anat Embryol 171:245-252.

Stevens CF, Tsujimoto T (1995) Estimates for the pool size of releasable quanta at a single central synapse and for the time required to refill the pool. Proc Natl Acad Sci USA 92:846-849.

Storck T, Schulte S, Hofmann K, Stoffel W (1992) Structure, expression, and functional analysis of a $\mathrm{Na}^{+}$-dependent glutamate/aspartate transporter from rat brain. Proc Natl Acad Sci USA 89:10955-10959.

Takahashi M, Sarantis M, Attwell D (1996) Postsynaptic glutamate uptake in rat cerebellar Purkinje cells. J Physiol (Lond) 497:523-530.

Tanaka K, Watase K, Manabe T, Yamada K, Watanabe M, Takahashi K, Iwama H, Nishikawa T, Ichihara N, Kikuchi T, Okuyama S, Kawashima N, Hori S, Takimoto M, Wada K (1997) Epilepsy and exacerbation of brain injury in mice lacking the glutamate transporter GLT-1. Science 276:1699-1702.

Tong G, Jahr CE (1994) Block of glutamate transporters potentiates postsynaptic excitation. Neuron 13:1195-1203.

Torp R, Danbolt NC, Babaie E, Bjørås M, Seeberg E, Storm-Mathisen J, Ottersen OP (1994) Differential expression of two glial glutamate transporters in the rat brain: an in situ hybridization study. Eur J Neurosci 6:936-942.

Torp R, Hoover F, Danbolt NC, Storm-Mathisen J, Ottersen OP (1997) Differential distribution of the glutamate transporters GLT1 and rEAAC1 in rat cerebral cortex and thalamus: an in situ hybridization analysis. Anat Embryol 195:317-326.

Towbin H, Staehelin T, Gordon J (1979) Electrophoretic transfer of proteins from polyacrylamide gels to nitrocellulose sheets: procedure and some applications. Proc Natl Acad Sci USA 76:4350-4354.

Ullensvang K, Lehre KP, Storm-Mathisen J, Danbolt NC (1997) Differential developmental expression of the two rat brain glutamate transporters GLAST and GLT. Eur J Neurosci 9:1646-1655.

Wadiche JI, Arriza JL, Amara SG, Kavanaugh MP (1995) Kinetics of a human glutamate transporter. Neuron 14:1019-1027.

Wenzel J, Lammert G, Meyer U, Krug M (1991) The influence of long-term potentiation on the spatial relationship between astrocyte processes and potentiated synapses in the dentate gyrus neuropil of rat brain. Brain Res 560:122-131.

Woolley CS, McEwen BS (1992) Estradiol mediates fluctuation in hippocampal synapse density during the estrous cycle in the adult rat. J Neurosci 12:2549-2554. 